Vol 2. No 1. Februari 2018

ISSN 2580-5029

\title{
PHENOTIPICAL CHARACTERS OF MELON (Cucumis melo L.) IN RESPONSE TO KARST CRITICAL LAND
}

\author{
Yuanita Rachmawati* ${ }^{*}$, Budi Setiadi Daryono², Ganies Riza Ariestya ${ }^{3}$ \\ 1 Universitas Islam Negeri Sunan Ampel of Surabaya, Indonesia \\ ${ }^{2}$ Gadjah Mada University of Yogyakarta, Indonesia \\ *Email: yuanitarhartono@gmail.com
}

\begin{abstract}
Yogyakarta Agroecosystem has 158,600 ha of critical land spread over three zones. Two areas are Karst Land, located on Agroecosystem II includes Gunungsewu Hills, Gunungkidul and III covers Dlingo Bantul Hills and Sentolo Hills Kulon Progo Regency.. Karst Land is certainly provides stress to plants. These research purposes are examining the phenotype character of superior melon Cultivar TACAPA compare to parents and offsprings phenotypes. The phenotype characters are based on plant height, leaf number, time of melon flowering, water content of plants, and fruit and seed productivity. This experiment was done by Split Plot Design with Completely Randomized Design (CRD) with 4 kinds of treatment (control plant media, Gunungsewu, Dlingo, and Sentolo), 7 experimental units cultivars: TACAPA, TA, TP, PT, AT, Action 434, PI 371795), and 4 replications. Research result reveals that most of the phenotypic characters including plant height, number of leaves, fruit weight, and number of seeds produced have relatively no significant effect between treatment and control, while the phenotypic first time flowering time and water content of the plant, have a noticeable difference.
\end{abstract}

Keywords: Phenotype, TACAPA Cultivars, Karst

\section{INTRODUCTION}

Karst is an area that has the specific and unique characteristics of relief and drainage, because the karst area drainage system is dominated by subsurface water mostly into the underground network. So that in the rainy season, water cannot be retained on the surface and directly into the ground (Nahdi, 2012). This karst condition also provides dehydration stress in plants because water cannot be absorbed optimally by plants caused directly into the underground layer. Grounds formed on main land such as limestone, limestone and glacial deposits, contain high levels of calcium carbonate $\left(\mathrm{CaCO}_{3}\right)$ and the soil is likely to have a $\mathrm{pH}$ of about 7 or more (Sutara, 1996). This condition is certainly provides stress to plants.

Yogyakarta Agroecosystem has 158,600 ha of critical land spread over three zones. Two areas are karst land, located on Agroecosystem II and III. Agroecosystem II includes Gunungsewu Hills, Gunungkidul, 
while Agroekosistem III covers Dlingo Bantul Hills and Sentolo Hills Kulon Progo Regency.

Some types of plants including melons, can grow and survive in conditions that are not optimum for its growth. This is because there are several mechanisms and strategies, can be done by an organism in a stressing environment, among others: Escaping, Avoidance, and Tolerance (Morgan, 1984; Mooney et al., 1987; Ingram and Bartels, 1996; Chaves et al., 2003).

Melon TACAPA is a cultivar that is being developed by Genetic Laboratory, Biology Faculty, Gadjah Mada University of Yogyakarta. This melon is a climacteric melon generated from a cross between PAction $434 \mathrm{X}$ ơPI 371795. TACAPA cultivar has superior properties of the merging properties from its parent, which is round oval shape with soft net, yellowish-green flesh, sweet taste, and resistant to powdery mildew flour mushrooms (Aristya, 2006 and 2009; Daryono and Qurrohman, 2009; Qurrohman, 2011; Rachmawati et al., 2016 and 2017).

In this research, Melon TACAPA is planting in greenhouse KP4 using soil media treatment taken from critical land area of Agro-ecosystem II and III. Then conducting the characterization of Melon TACAPA in terms of phenotype. Phenotypic characters collected include plant height, leaf number, time of melon flowering, water content of plants, and fruit and seed productivity. The study also compared the phenotypic characteristics obtained in TACAPA with TACAPA parents cultivar, namely Action 434 and PI 371795, and TACAPA offsprings namely TA, TP, PT, and AT cultivars.

\section{METHODS}

\section{Greenhouse Experiment}

The experiment of greenhouse was done in KP4 UGM Berbah, Sleman - DI Yogyakarta. This experiment was done by Split Plot Design with Completely Randomized Design (CRD) with 4 kinds of treatment (control plant media, Gunungsewu, Dlingo, and Sentolo), 7 experimental units cultivars: TACAPA, TA, TP, PT, AT, Action 434, PI 371795), and 4 replications. Phenotypic data that became the unit of observation include plant height, leaf number, time of melon flowering, water content of plants, and fruit and seed productivity. Watering is done 3 times a week with the amount of water $(500 \mathrm{ml})$ controlled for each plant pot. NPK fertilizer is also given 2 times a month with the amount (1 tablespoon) that is controlled. Pest and disease control is done by spraying insecticide once a month with a concentration of $2 \mathrm{cc}$ in 1 liter of water.

\section{Data Analysis}

The collected phenotype data were plant height, leaf number, flowering time of melon, water content of plant, and fruit and seed productivity, then analyzed by using SAS 9.0 Portable program at 5\% test level. If this $F$ test indicates any significant 
difference characters, then test will continue to proceed with Duncan Multiple Range Test (DMRT) at a standard 5\% test level.

\section{RESULT AND DISCUSSION}

The research began with critical land surveys and determination of coordinate points using Garmin GPS. Agroecosystem II and III region which are spread over 3 areas of DI Yogyakarta, Gunungsewu in Gunungkidul District have coordinates: $110^{\circ} 32^{\prime} 15.7^{\prime \prime}$ of longitude and $08^{\circ} 03^{\prime} 36.7^{\prime \prime}$ of latitude at the elevation: $265 \mathrm{~m}$ asl. Dlingo District of Bantul with coordinates: $110^{\circ} 27^{\prime} 56.2^{\prime \prime}$ of longitude and 07055'58.7" of latitude with elevation: $230 \mathrm{~m}$ asl, and Sentolo Kulon Progo Regency with coordinates: $110^{\circ} 11^{\prime} 11.3^{\prime \prime}$ of longitude LS: 07049'56.5" of latitude with elevation at
$116 \mathrm{~m}$ asl. The greenhouse temperature ranged from $27^{\circ} \mathrm{C}$ to $43^{\circ} \mathrm{C}$ during the time of observation.

Data results was showed in a table with the phenotypic characteristics obtained in TACAPA and TACAPA parents cultivar, namely ACTION 434 and PI 371795, and TACAPA offsprings namely TA, TP, PT, and AT cultivars.

\section{PHENOTIPICAL CHARACTERS}

\section{PLANT HEIGHT}

Plant height is the result of plant growth and development process which can be used as parameter in describing plant growth in certain condition. In this study, plant height was used as a unit of observation which was then analyzed by Duncan test of $5 \%$ level. The results presented in Table 1.

Table 1. Effect of critical soil treatment on TACAPA cultivar melon plant height, TACAPA parents and offsprings of TACAPA at 9th week

\begin{tabular}{|c|c|c|c|c|c|c|c|c|}
\hline \multirow{2}{*}{ T } & \multicolumn{7}{|c|}{ Cultivar Melon } & ACTION \\
\cline { 2 - 9 } & TACAPA & TA & TP & PT & AT & $\begin{array}{c}\text { PI } \\
\mathbf{3 7 1 7 9 5}\end{array}$ & Average \\
\hline C & $156.25 \mathrm{a}$ & $157.50 \mathrm{a}$ & $194.00 \mathrm{a}$ & $192.50 \mathrm{ab}$ & $207.50 \mathrm{a}$ & $157.75 \mathrm{a}$ & $180.25 \mathrm{a}$ & $178.500 \mathrm{a}$ \\
\hline GK & $141.50 \mathrm{a}$ & $197.50 \mathrm{a}$ & $174.75 \mathrm{ab}$ & $220.25 \mathrm{a}$ & $202.75 \mathrm{a}$ & $146.50 \mathrm{a}$ & $145.75 \mathrm{a}$ & $177.679 \mathrm{a}$ \\
\hline D & $160.00 \mathrm{~b}$ & $160.00 \mathrm{a}$ & $138.75 \mathrm{c}$ & $138.50 \mathrm{~b}$ & $142.75 \mathrm{~b}$ & $148.50 \mathrm{a}$ & $148.25 \mathrm{a}$ & $139.500 \mathrm{~b}$ \\
\hline S & $99.75 \mathrm{a}$ & $164.50 \mathrm{a}$ & $156.25 \mathrm{bc}$ & $166.75 \mathrm{ab}$ & $183.00 \mathrm{ab}$ & $156.50 \mathrm{a}$ & $189.50 \mathrm{a}$ & $165.429 \mathrm{a}$ \\
\hline
\end{tabular}

Explanation:

The numbers are listed in units of $\mathrm{cm}$.

T: Treatment, C: Control, GK: Gunungkidul, D: Dlingo, S: Sentolo

Numbers followed by the same letter in the same column show results that are not significantly different in Duncan's Duncan (DMRT) range test of 5\% level.

Duncan test results analysis of the critical land influence on plants cultivars in general shows that only Dlingo critical land that gives a significant effect on the average of melon cultivars height. The same thing was seen in the high yield of melon of TACAPA. This indicates that Dlingo's critical lands give greater stressful effects than other critical lands and controls. While TACAPA, ACTION 434 and PI 371795 and its offsprings, ie TA showed no different results between treatment and control. 


\section{TOTAL LEAVES AMOUNT}

Leaves are parts of plants that are important for the place of photosynthesis activities. Leaf observation is needed in addition as an indicator of growth as well as supporting data in explaining the growth process that occurs. The data obtained is presented in Table 2.

Table 2. Effect of critical soil treatments on the number of TACAPA cultivar melon leaves, TACAPA parent and TACAPA crosses result at 9 th week

\begin{tabular}{|c|c|c|c|c|c|c|c|c|}
\hline \multirow{2}{*}{ T } & \multicolumn{7}{|c|}{ Cultivar } & \multirow{2}{*}{ Average } \\
\cline { 2 - 8 } & TACAPA & TA & TP & PT & AT & $\begin{array}{c}\text { ACTION } \\
\mathbf{4 3 4}\end{array}$ & $\begin{array}{c}\text { PI } \\
\mathbf{3 7 1 7 9 5}\end{array}$ & \\
\hline C & $29.00 \mathrm{a}$ & $31.75 \mathrm{c}$ & $49.75 \mathrm{a}$ & $63.25 \mathrm{a}$ & $75.50 \mathrm{a}$ & $64.50 \mathrm{ab}$ & $60.25 \mathrm{a}$ & $53.429 \mathrm{~b}$ \\
\hline GK & $47.50 \mathrm{a}$ & $84.50 \mathrm{a}$ & $54.50 \mathrm{a}$ & $78.00 \mathrm{a}$ & $74.00 \mathrm{a}$ & $105.00 \mathrm{a}$ & $68.50 \mathrm{a}$ & $73.143 \mathrm{a}$ \\
\hline D & $20.00 \mathrm{~b}$ & $79.75 \mathrm{ab}$ & $55.75 \mathrm{a}$ & $36.50 \mathrm{a}$ & $66.50 \mathrm{a}$ & $77.00 \mathrm{ab}$ & $56.00 \mathrm{a}$ & $55.929 \mathrm{~b}$ \\
\hline S & $23.00 \mathrm{~b}$ & $47.75 \mathrm{bc}$ & $23.75 \mathrm{a}$ & $45.75 \mathrm{a}$ & $54.50 \mathrm{a}$ & $41.75 \mathrm{~b}$ & $80.50 \mathrm{a}$ & $45.286 \mathrm{~b}$ \\
\hline
\end{tabular}

Explanation:

The numbers are listed in units of pcs.

T: Treatment, C: Control, GK: Gunungkidul, D: Dlingo, S: Sentolo

Numbers followed by the same letter in the same column show results that are not significantly different in Duncan's Duncan (DMRT) range test of 5\% level.

Many of the leaves that are formed are determined by the ability of plants to allocate photosintate for the development of leaf primodia. The result of Duncan test analysis of the critical land influence on the plant cultivar generally showed no significant difference between the control with Dlingo and Sentolo critical soil treatment on the average number of melon leaves in the observation of week IX. In TACAPA melon, Dlingo and Sentolo treatments have a significant effect when compared to the control and treatment of Gunungsewu. This indicates that Dlingo and Sentolo's critical lands give obstacles to the ability of plants to allocate photosynthesis to the development of leaf primodias. While TACAPA, PI 371795 as well as its derivatives, TP, PT, and AT showed no different result between treatment and control.
Most of the results showed no significant effect of treatment on the number of leaves. However, it is possible to make a difference in the physiological and anatomical characteristics of plants. This is as described in the research Kowalczyk (1967) on Carnation plants, stress on plants in the form of water causes the leaves to be narrow but thick. This is due to cell growth restriction, both cleavage and cell resistance and waxy / thickening of cell wall to keep cell contents in optimum condition, especially moisture content.

Stress in plants will cause the leaves to decrease the process of photosynthesis and premature aging of the leaf /early senescence. This is explained by Farooq et al. (2009) because in stressful conditions, ABA hormones will be more expressed to regulate open and close stomata in order to prevent excessive transpiration. More 
frequent stomatal closures will cause the rate of photosynthesis to decline and growth becomes inhibited.

\section{FLOWERING TIME}

Observation unit of flowering time of melon plants needs to be observed. Several studies have shown that plant environment stress will have an effect on the acceleration of flowering induction of plants (Stephen \& Davenport, 1986; Mwanamwenge et al., 1999). In this study, observed the first time melon flowering, presented in Table 3.

Table 3. Effect of critical land treatment on flowering time of TACAPA cultivar melon, TACAPA cultivation and TACAPA crosses

\begin{tabular}{|c|c|c|c|c|c|c|c|c|}
\hline \multirow{2}{*}{ T } & \multicolumn{7}{|c|}{ Cultivar } & \multirow{2}{*}{ Average } \\
\cline { 2 - 9 } & TACAPA & TA & TP & PT & AT & $\begin{array}{c}\text { ACTION } \\
\mathbf{4 3 4}\end{array}$ & $\begin{array}{c}\text { PI } \\
\mathbf{3 7 1 7 9 5}\end{array}$ & \\
\hline C & $27.250 \mathrm{a}$ & $31.000 \mathrm{a}$ & $25.500 \mathrm{a}$ & $33.000 \mathrm{a}$ & $28.500 \mathrm{a}$ & $26.750 \mathrm{a}$ & $25.500 \mathrm{a}$ & $28.2143 \mathrm{a}$ \\
\hline GK & $25.500 \mathrm{ab}$ & $27.500 \mathrm{~b}$ & $22.500 \mathrm{a}$ & $28.500 \mathrm{~b}$ & $28.000 \mathrm{a}$ & $24.500 \mathrm{ab}$ & $25.000 \mathrm{a}$ & $25.9286 \mathrm{~b}$ \\
\hline D & $25.500 \mathrm{ab}$ & $31.000 \mathrm{a}$ & $25.000 \mathrm{a}$ & $27.000 \mathrm{~b}$ & $27.000 \mathrm{a}$ & $22.500 \mathrm{~b}$ & $23.000 \mathrm{a}$ & $25.8571 \mathrm{~b}$ \\
\hline S & $24.500 \mathrm{~b}$ & $31.000 \mathrm{a}$ & $23.000 \mathrm{a}$ & $27.750 \mathrm{~b}$ & $25.500 \mathrm{a}$ & $23.000 \mathrm{~b}$ & $23.000 \mathrm{a}$ & $25.3929 \mathrm{~b}$ \\
\hline
\end{tabular}

Explanation:

The numbers are listed in units of day.

T: Treatment, C: Control, GK: Gunungkidul, D: Dlingo, S: Sentolo

Numbers followed by the same letter in the same column show results that are not significantly different in Duncan's Duncan (DMRT) range test of 5\% level.

Giving critical land treatment both Gunung Kidul, Dlingo, and Sentolo, significantly effect on the first flowering time in melon plants. This critical soil treatment induces the acceleration of flowering in melon plants with an average flowering of 25-26 days, while at 28 day control. This can be an indicator that a plant is stressed. According to Poerwanto (2014), stress conditions in plants, especially water stress is a factor of induced flowering plants. This is because, stress will inhibit the growth of plants due to inhibition of giberelin biosynthesis and the occurrence of hydrolysis of starch into simple sugars will make the plants experience a more rapid flowering. Poerwanto added that the technique of stress especially drought is important to do in the tropics to provide a different harvest time interval.

Research data on each cultivar also showed mixed results. In TACAPA cultivars, the influence of Sentolo planting medium will induce the most rapid flowering when compared to other treatments. The fastest flowering induction occurred in the treated cultivars of ACTION 434 treated by Dlingo and Sentolo media. While for PI 371795, AT, and $\mathrm{TP}$, giving stress environment did not give significant influence to flowering induction. A study by Stephen \& Davenport (1986) showed that the water-suppressed Citrus plant provides an induction of accelerated flowering of plants with a higher number of flowers than controls. Arrangement in flowering time is the right 
step to adapt to unoptimum environmental conditions. The escaping strategy to accelerate flowering by a plant is an effective strategy to minimize lost productivity, by accelerating maturity to shorten the stress period (Farooq et al., 2009).

\section{WATER DEGREE}

Water is a very important compound for plant growth and is needed in very large quantities. Water is an important component of the plant, forming $80-90 \%$ fresh weight of actively growing tissue. In this study the water content of the plant is calculated based on the value of Wet and Dry Weights. The results of statistical analysis of water grade values of plants are presented in Table 4.

Table 4. Effect of critical soil treatment on the water content of plants on TACAPA cultivar melons, TACAPA parent and TACAPA crosses

\begin{tabular}{|c|c|c|c|c|c|c|c|c|}
\hline \multirow{2}{*}{ T } & \multicolumn{7}{|c|}{ Cultivar } & \multirow{2}{*}{ Average } \\
\cline { 2 - 9 } & TACAPA & TA & TP & PT & AT & $\begin{array}{c}\text { ACTION } \\
\mathbf{4 3 4}\end{array}$ & $\begin{array}{c}\text { PI } \\
\mathbf{3 7 1 7 9 5}\end{array}$ & \\
\hline C & $83.2550 \mathrm{a}$ & $77.785 \mathrm{a}$ & $74.3275 \mathrm{a}$ & $75.338 \mathrm{a}$ & $79.7375 \mathrm{a}$ & $76.9325 \mathrm{a}$ & $77.0225 \mathrm{a}$ & $77.7711 \mathrm{a}$ \\
\hline GK & $80.9125 \mathrm{~b}$ & $72.165 \mathrm{~b}$ & $74.9100 \mathrm{a}$ & $73.740 \mathrm{a}$ & $72.2900 \mathrm{bc}$ & $70.4375 \mathrm{~b}$ & $70.3975 \mathrm{~b}$ & $73.5504 \mathrm{~b}$ \\
\hline D & $80.3200 \mathrm{~b}$ & $73.120 \mathrm{~b}$ & $73.6675 \mathrm{a}$ & $73.750 \mathrm{a}$ & $73.1125 \mathrm{~b}$ & $67.0725 \mathrm{c}$ & $71.5675 \mathrm{~b}$ & $73.2075 \mathrm{bc}$ \\
\hline S & $80.1625 \mathrm{~b}$ & $71.643 \mathrm{~b}$ & $72.1425 \mathrm{~b}$ & $73.465 \mathrm{a}$ & $70.8875 \mathrm{c}$ & $69.1750 \mathrm{~b}$ & $71.7075 \mathrm{~b}$ & $72.7629 \mathrm{c}$ \\
\hline
\end{tabular}

Explanation:

The numbers are listed in units of \%.

T: Treatment, C: Control, GK: Gunungkidul, D: Dlingo, S: Sentolo

Numbers followed by the same letter in the same column show results that are not significantly different in Duncan's Duncan (DMRT) range test of $5 \%$ level.

Water as an essential component of the plant has a role, among others: a) As a solvent, in it there are gases, salts, and other solutes moving in and out of the cell, b) As reagents in photosynthesis and various hydrological processes, c) young or other structures (Levitt, 1980). This water content is allocated to plant parts that have high physiological activity. Levitt (1980) also adds that dehydration in plants can be avoided either by minimizing outgoing water by stomata closure, leaf rolls, leaf dropping, reducing growth and shortening ontogenesis, or by maintaining a water supply with osmotic adjustment and an increase in the root / canal ratio.

In the melon water content results obtained a distinct percentage of real between all treatments. The smallest percentage value is obtained at Dlingo and Sentolo treatment. This indicates that both of these treatments provide greater stress conditions than the treatment of Gunungkidul and control. A small percentage of the water content of plants shows that water given to plants through the soil, at least to be absorbed by plants. 
The results of data obtained on the effect of treatment on each cultivar showed that the data are uniform. Both on TACAPA water content, TACAPA, and TACAPA breeds explain that Dlingo and Sentolo treatments provide greater dehydration when compared to controls. Dlingo and Sentolo ground which are yellowish in color tend to be white and solid (typical karst soil) it is more difficult to hold water as moisture, so with the same watering volume the plant roots absorb water in less amount than the treatment of Gunungkidul and control.

Setiawan et al. (2013) mentions in his research on Patchouli that the decrease of moisture value along with the watering interval, the longer the plants get the water supply, the lower the value. This is due to the longer watering interval, the plant roots also absorb water in less amount compared to the shorter watering intervals.

\section{MELON FRUITS}

Melon fruit derived from various cultivars with some treatment in this study, can also be harvested. But not all plants have fruit with a perfect phenotype. Some plants do not produce fruit until they can be harvested and some produce fruit with malformations (imperfect forms). The amount of fruit that can be harvested in each treatment can be seen in Figure 1, while the number of fruits of each cultivar can be seen in Figure 2.

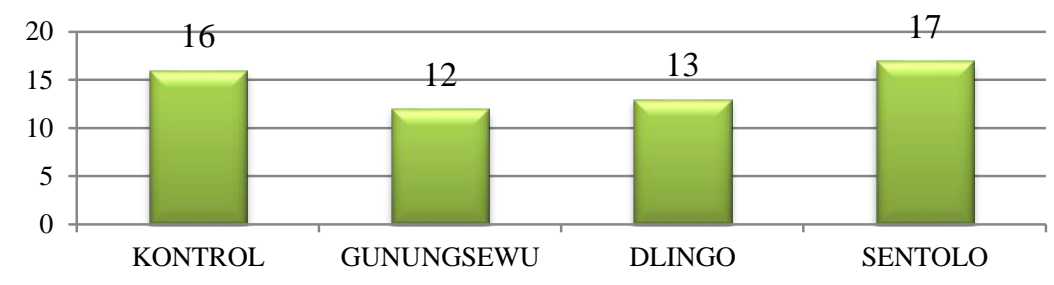

Figure 1. Amount of Harvested Fruits for each of Plant Medium

Critical land treatment does not prevent plants from producing fruit. It is seen that the Sentolo critical land used as a growing medium has more fruit products than controls.

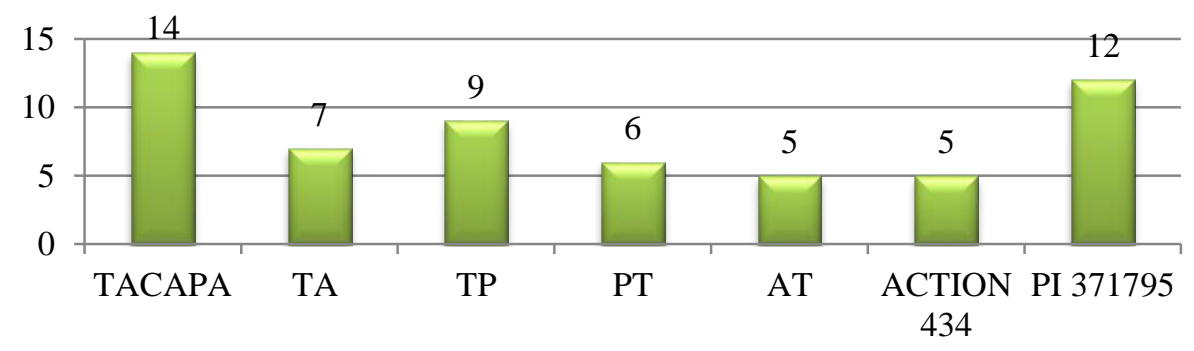

Figure 2. Amount of Harvested Fruits for each of Cultivar

TACAPA cultivars have an advantage over other cultivars in terms of fruit productivity as indicated by the maximum number of fruits that can and the resulting 
fruit have a relatively lower percentage of malformations compared to other cultivars. This indicates that TACAPA cultivars are more likely to be developed on land with a medium similar to those in this study. Figure 3 shows the percentage of malformations in each cultivar.

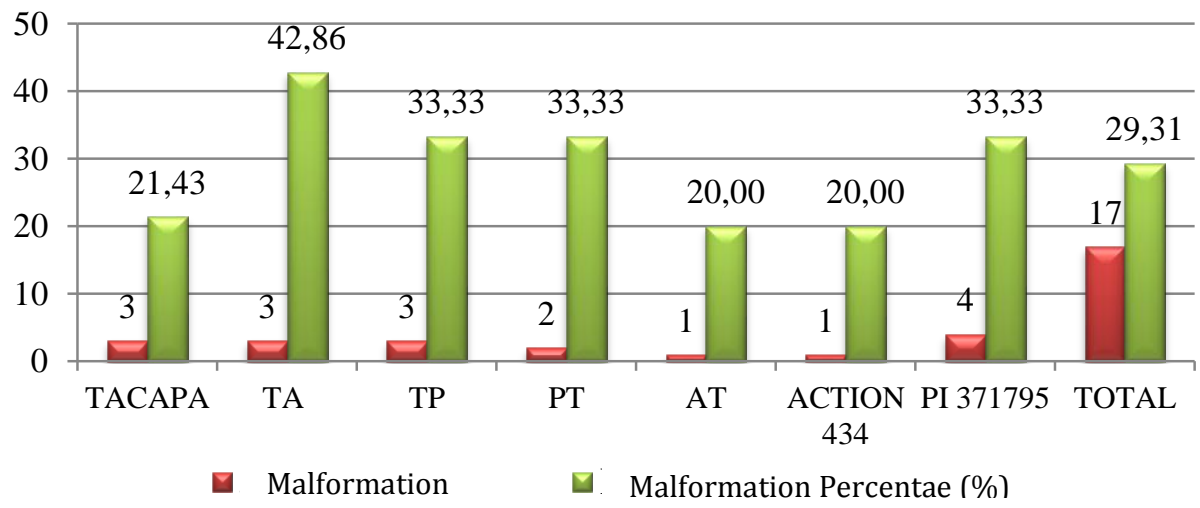

Figure 3. Histogram of malformation amount and percentage for each of Cultivar

Malformations can be caused by several factors, one of which is imperfect pollination. This may be due to the lack of pollinator insects, low pollen viability due to climate and environmental influences, and other factors (Easterbrook \& Cross, 1992). Easterbrook \& Cross (1992) adds that the development of pollen may also be inhibited by insufficient nutrients leading to fruit malformations. Another study also mentioned that the administration of pesticides can also trigger the occurrence of malformations in the fruit (Bennet, 1969, Takahashi 1973).

The fruits that have been harvested are then weighed to determine the weight of the fruit (g). The average data of fruit weight and the results of Duncan's advanced assay analysis are presented in Table 5.

Table 5. Effect of critical soil treatments on the weight of TACAPA fruits, TACAPA parent and TACAPA offsprings

\begin{tabular}{|c|c|c|c|c|c|c|c|c|}
\hline \multirow{2}{*}{ T } & \multicolumn{7}{|c|}{ Cultivar } & \multirow{2}{*}{ Average } \\
\cline { 2 - 8 } & TACAPA & TA & TP & PT & AT & $\begin{array}{c}\text { ACTION } \\
\mathbf{4 3 4}\end{array}$ & $\begin{array}{c}\text { PI } \\
\mathbf{3 7 1 7 9 5}\end{array}$ & \\
\hline C & $279.98 \mathrm{a}$ & $346.43 \mathrm{a}$ & $251.30 \mathrm{a}$ & $220.85 \mathrm{a}$ & $237.50 \mathrm{a}$ & $242.50 \mathrm{a}$ & $142.60 \mathrm{a}$ & $250.71 \mathrm{a}$ \\
\hline GK & $117.75 \mathrm{~b}$ & $241.00 \mathrm{ab}$ & $165.40 \mathrm{a}$ & $140.40 \mathrm{~b}$ & $121.70 \mathrm{a}$ & $110.10 \mathrm{a}$ & $126.95 \mathrm{a}$ & $140.61 \mathrm{c}$ \\
\hline $\mathbf{D}$ & $203.55 \mathrm{ab}$ & $166.10 \mathrm{~b}$ & $142.55 \mathrm{a}$ & $206.20 \mathrm{~b}$ & $186.60 \mathrm{a}$ & $188.20 \mathrm{a}$ & $183.07 \mathrm{a}$ & $184.28 \mathrm{~b}$ \\
\hline S & $224.83 \mathrm{a}$ & $323.45 \mathrm{a}$ & $169.20 \mathrm{a}$ & $200.35 \mathrm{~b}$ & $248.05 \mathrm{a}$ & $254.90 \mathrm{a}$ & $191.20 \mathrm{a}$ & $226.04 \mathrm{a}$ \\
\hline
\end{tabular}

Explanation:

The numbers are listed in units of gr.

T: Treatment, C: Control, GK: Gunungkidul, D: Dlingo, S: Sentolo

Numbers followed by the same letter in the same column show results that are not significantly different in Duncan's Duncan (DMRT) range test of 5\% level. 


\section{BIOTROPIC The Journal of Tropical Biology}

Vol 2. No 1. Februari 2018

ISSN 2580-5029

Fruit weight data indicates that the largest average fruit weight is in the control. This is due to the control, the water can be absorbed perfectly by plants and nutrients can be transported more optimum than the existence of critical soil treatment so that the fruit generated has a larger average size and

heavier.

\section{SEED PHENOTYPE}

Table 6. Effect of critical land treatment on the productivity of TACAPA cultivar melon seeds, TACAPA parent, and TACAPA crosses

\begin{tabular}{|c|c|c|c|c|c|c|c|c|}
\hline \multirow{2}{*}{ T } & \multicolumn{7}{|c|}{ Cultivar } & \multirow{2}{*}{ Average } \\
\cline { 2 - 9 } & TACAPA & TA & TP & PT & AT & $\begin{array}{c}\text { ACTION } \\
\mathbf{4 3 4}\end{array}$ & $\begin{array}{c}\text { PI } \\
\mathbf{3 7 1 7 9 5}\end{array}$ & \\
\hline C & $242.00 \mathrm{a}$ & $241.33 \mathrm{a}$ & $266.00 \mathrm{a}$ & $114.00 \mathrm{a}$ & $128.00 \mathrm{a}$ & $150.00 \mathrm{a}$ & $138.67 \mathrm{a}$ & $196.63 \mathrm{a}$ \\
\hline GK & $205.75 \mathrm{a}$ & $179.00 \mathrm{a}$ & $207.00 \mathrm{a}$ & $131.00 \mathrm{a}$ & $142.00 \mathrm{a}$ & $69.00 \mathrm{a}$ & $169.25 \mathrm{a}$ & $165.46 \mathrm{a}$ \\
\hline D & $190.33 \mathrm{a}$ & $133.00 \mathrm{a}$ & $252.00 \mathrm{a}$ & $227.00 \mathrm{a}$ & $94.00 \mathrm{a}$ & $196.00 \mathrm{a}$ & $201.33 \mathrm{a}$ & $194.08 \mathrm{a}$ \\
\hline S & $179.67 \mathrm{a}$ & $121.00 \mathrm{a}$ & $180.67 \mathrm{a}$ & $208.50 \mathrm{a}$ & $109.50 \mathrm{a}$ & $229.00 \mathrm{a}$ & $171.50 \mathrm{a}$ & $179.06 \mathrm{a}$ \\
\hline
\end{tabular}

Explanation:

The numbers are listed in units of pcs.

T: Treatment, C: Control, GK: Gunungkidul, D: Dlingo, S: Sentolo

Numbers followed by the same letter in the same column show results that are not significantly different in Duncan's Duncan (DMRT) range test of 5\% level.

Table 6. provides information on seed productivity data shown on the number of seeds produced by melons either between the controls with each treatment and between the cultivars with each other. The data analysis performed resulted that the influence of the critical land between control and each treatment and between cultivars did not show any significant difference.

\section{CONCLUSSION}

Most of the phenotypic characters including plant height, number of leaves, fruit weight, and number of seeds produced have relatively no significant effect between treatment and control, while the phenotypic first time flowering time and water content of the plant, have a noticeable difference.

\section{AKNOWLEDGEMENT}

Acknowledgments are given to the Indonesian Ministry of Research and Technology for grant aid through the INSINAS program knowing the 2013-2014 budgeting years that has been given to the research team of Genetics Laboratory of Faculty of Biology Gadjah Mada University of Yogyakarta.

\section{REFERENCES}

Aristya, G. R. 2006. Skrining dan Pewarisan Sifat Ketahanan Tanaman Melon (Cucumis melo L.) terhadap Powder Mildew (Jamur Tepung). Skripsi Fakultas Biologi Universitas Gadjah Mada Yogyakarta.

Aristya, G. R. 2009. Pewarisan dan Pemetaan Penanda Sequence Characterized Amplified Region (SCAR) Terpaut Gen Penyandi Ketahanan Powdery 
Mildew (Podosphaera xanthii (Castag.) Braun et Shiskoff) pada Tanaman Melon (Cucumis melo L.). Tesis Fakultas Biologi Universitas Gadjah Mada Yogyakarta.

Bennet, M. 1969. Field Control of Strawberry Fruit-rot (Botrytis cinerea Fr.) by Fungiside. Journal of Horticultural Science 44:81-89.

Chaves, M. M., Maroco, J. P., \& Pereira, J. S. 2003. Understanding Plant Responses to Drought from Genes to The Whole Plant Function. Journal of Plant Biology 30:239-264.

Daryono, B. S. \& Qurrohman, M. T. 2009. Pewarisan Sifat Ketahanan Melon (Cucumis melo L.) Terhadap Powdery Mildew (Podosphaera xantii (Castag.) Braun et Shishkoff). Jurnal Perlindungan Tanaman Indonesia 15(1):1-6.

Easterbrook, M. A. \& Cross, J. V. 1992. The Role of Capsid Bugs in Malformation of Strawberry. Cambridgeshire: Horticulture Research International.

Farooq, M., Wahid, A., Kobayashi, N., Fujita, D., \& Basra, S. M. A. 2009. Plant Drought Stress: Effects, Mechanisms and Management. Journal Agronomy for Sustainable Development 29:185212.

Ingram, J. \& Bartels, D. 1996. The Molecular Basis of Dehydration Tolerance in Plants. Annual Review Plant Physiology. Journal of Plant Molecular Biology 47:377-403.

Kowalczyk, R. A. 1967. The Effect of Soil Moisture Stress on Growth and Flowering of Carnations. Thesis Colorado States University.

Levitt, J. 1980. Response of Plants to Environmental Stresses: Water, Radiation, Salt, and Other Stresses. NewYork: Academic Press.
Mooney, H. A., Pearcy, R. W., \& Ehleringer, J. 1987. Plant Physiology Ecology Today. Journal of Bioscience 7:18-20.

Morgan, J. M. 1984. Osmoregulation and Water Stress in Higher Plants. Annual Review Plant Physiology. Journal of Plant Molecular Biology 35:299-319.

Mwanamwenge, J., Loss, S. P., Siddique, K. H. M., \& Cocks, P. S. 1999. Effect of Water Stress During Floral Initiation, Flowering and Podding on The Growth and Yield of Faba Bean (Vicia faba L.). European Journal of Agronomy 1:1-11.

Nahdi, M. S. 2012. Konservasi Ekosistem Lahan Kritis Berbasis Kearifan Masyarakat di Kawasan Imogiri Yogyakarta. Disertasi Fakultas Biologi Universitas Gadjah Mada Yogyakarta.

Poerwanto, R. 2014. Materi Perkuliahan: Pembungaan dan Pembuahan. Departemen Agronomi dan Hortikultura, Institut Pertanian Bogor.

Qurrohman, M. T. 2011. Analisis Keterpautan Gen Ketahanan terhadap Powdery Mildew pada Tanaman Melon (Cucumis melo L.) Hasil Test Cross dengan Penanda Sequence Characterized Amplified Region (SCAR). Tesis Fakultas Biologi Universitas Gadjah Mada Yogyakarta.

Rachmawati, Y., Budi, S. D., \& Ganies, R. A. 2017. Molecular characters of melon (Cucumismelo L."Tacapa”) in response to karst critical land. AIP Conference Proceedings 1854 (1), 020030.

Setiawan. 2012. Respon Tanaman Nilam (Pogostemon cablin Benth) terhadap Cekaman Kekeringan. Tesis Fakultas Pertanian UGM. 
Stephen, S. M. \& Davenport T. L. 1986. Characterization of Water Stress and Low Temperature Effects on Flower Induction in Citrus. Journal of Plant Physiology 81:26-29.

Sutara, P. K. 1996. Struktur Anatomi Eichornia crassipes (Mart.) Solm. dan Pistia stratiotes L. Akibat Pemberian Naphtol dan Kalsium
Karbonat. Tesis Fakultas Matematika dan Ilmu Pengetahuan Alam Universitas Gadjah Mada Yogyakarta.

Takahashi, K. 1973. Factors Affecting Malformation of Strawberry Fruit in Plastic Greenhouse. Acta Horticulturae 30:179-185. 